\title{
2-acetylphenol analogs as potent reversible monoamine oxidase inhibitors
}

\author{
This article was published in the following Dove Press journal: \\ Drug Design, Development and Therapy \\ 15 July 2015 \\ Number of times this article has been viewed
}

\author{
Lesetja J Legoabe' \\ Anél Petzer' \\ Jacobus P Petzer ${ }^{1,2}$ \\ 'Centre of Excellence for \\ Pharmaceutical Sciences, ${ }^{2}$ Department \\ of Pharmaceutical Chemistry, School \\ of Pharmacy, North-West University, \\ Potchefstroom, South Africa
}

\begin{abstract}
Based on a previous report that substituted 2-acetylphenols may be promising leads for the design of novel monoamine oxidase (MAO) inhibitors, a series of C5-substituted 2-acetylphenol analogs (15) and related compounds (two) were synthesized and evaluated as inhibitors of human MAO-A and MAO-B. Generally, the study compounds exhibited inhibitory activities against both MAO-A and MAO-B, with selectivity for the $\mathrm{B}$ isoform. Among the compounds evaluated, seven compounds exhibited $\mathrm{IC}_{50}$ values $<0.01 \mu \mathrm{M}$ for MAO-B inhibition, with the most selective compound being 17,000-fold selective for MAO-B over the MAO-A isoform. Analyses of the structure-activity relationships for MAO inhibition show that substitution on the $\mathrm{C} 5$ position of the 2-acetylphenol moiety is a requirement for MAO-B inhibition, and the benzyloxy substituent is particularly favorable in this regard. This study concludes that C5-substituted 2-acetylphenol analogs are potent and selective MAO-B inhibitors, appropriate for the design of therapies for neurodegenerative disorders such as Parkinson's disease.
\end{abstract}

Keywords: monoamine oxidase, MAO, inhibition, 2-acetylphenol, structure-activity relationship

\section{Introduction}

Parkinson's disease is a degenerative disorder of the central nervous system. ${ }^{1}$ One of the main pathological characteristics of Parkinson's disease is the destruction of the dopamine-containing neurons of the nigrostriatal pathway, which results in the deficiency of dopamine at the nerve terminals in the corpus striatum. ${ }^{1}$ The cornerstone of Parkinson's disease therapy is the replacement of the lost dopamine with its direct metabolic precursor, L-3,4-dihydroxyphenylalanine (L-dopa). ${ }^{2}$ To enhance the therapeutic efficacy of L-dopa and to reduce the occurrence of L-dopa-associated side effects, this drug is frequently administered in combination with inhibitors of the enzymes, peripheral dopa decarboxylase, and catechol-O-methyl transferase. ${ }^{3,4}$ The inhibition of these enzymes prevents the peripheral metabolism of L-dopa and allows for the effective L-dopa dose to be reduced. ${ }^{5}$ A second strategy to increase the efficacy of L-dopa is to inhibit the metabolism of dopamine with monoamine oxidase (MAO) type B inhibitors. ${ }^{6}$ In the central nervous system, MAO-B is a major catabolic enzyme of dopamine, and inhibition of this enzyme conserves the central dopamine supply. ${ }^{7}$ L-dopa is thus frequently also combined with MAO-B inhibitors with the aim of further enhancing central dopamine levels. ${ }^{8-10}$ In early Parkinson's disease, monotherapy with MAO-B inhibitors may delay the necessity for L-dopa therapy. ${ }^{11}$

MAO consists of two distinct isoforms, MAO-A and MAO-B. Although both isoforms metabolize dopamine in the central nervous system, only MAO-B inhibitors are used in Parkinson's disease, in part because MAO-B activity is higher than that of MAO-A in the affected region, the basal ganglia. ${ }^{6} \mathrm{MAO}-\mathrm{A}$ inhibitors have

submit your manuscript | www.dovepress.con 
been used in the clinic as antidepressants, ${ }^{12,13}$ but their use is restricted by the occurrence of a potentially fatal hypertensive response when taken with tyramine-containing foods. ${ }^{14}$ This adverse effect is, however, mostly caused by irreversible MAO-A inhibitors, and the newer generation reversible inhibitors appear to be safe in this regard. ${ }^{15,16}$ Both reversible and irreversible MAO-B inhibitors, on the other hand, have excellent safety profiles and are not associated with a hypertensive response. ${ }^{17}$ Currently, two irreversible MAO-B inhibitors, selegiline [ $R)$-deprenyl] and rasagiline, are employed in the clinic for the treatment of Parkinson's disease. Based on the patent literature, many research groups are actively developing MAO inhibitors, and many of them intended for the treatment of Parkinson's disease. $^{18}$

Since MAO-B inhibitors are considered useful agents for the management of Parkinson's disease, the goal of this study was to discover novel MAO inhibitors. Such compounds should possess selectivity for the MAO-B isoform. In a recent study, we have shown that substituted 2-acetylphenols are promising leads for the design of MAO-B inhibitors. ${ }^{19}$ In the reported study, a limited series of six 2-acetylphenol analogs $(\mathbf{1} \mathbf{a}-\mathbf{f})$ were synthesized, and it was found that substitution on the C5 position (eg, 1e and 1f) was particularly favorable for high potency MAO-B inhibition (Table 1). Compounds $\mathbf{1 e}$ and $\mathbf{1 f}$ thus represent exceptionally potent MAO-B inhibitors with $\mathrm{IC}_{50}$ values of $0.004 \mu \mathrm{M}$ and $0.011 \mu \mathrm{M}$, respectively. Substitution on C4 (1c, 1d) and C3 (1a, 1b), on the other hand, yielded lower potency MAO-B inhibitors. The 2-acetylphenols were

Table I The $\mathrm{IC}_{50}$ values for the inhibition of recombinant human MAO-A and MAO-B by previously reported 2-acetylphenol analogs $\mathbf{I} \mathbf{a}-\mathbf{f}^{\mid 9}$

\begin{tabular}{|c|c|c|c|c|}
\hline $1 \mathbf{a}-\mathbf{b}$ & $1 \mathrm{c}-$ & & $\mathbf{R}^{-}$ & $-f$ \\
\hline \multirow[t]{2}{*}{ Compound } & \multirow[t]{2}{*}{$\mathbf{R}$} & \multicolumn{2}{|l|}{$I C_{50}(\mu M)$} & \multirow[t]{2}{*}{$\mathbf{S} \mathbf{I}^{\mathbf{a}}$} \\
\hline & & MAO-A & MAO-B & \\
\hline Ia & $\left(3-\mathrm{BrC}_{6} \mathrm{H}_{4}\right) \mathrm{CH}_{2} \mathrm{O}-$ & 103 & 5.96 & 17 \\
\hline Ib & $\left(4-\mathrm{BrC}_{6} \mathrm{H}_{4}\right) \mathrm{CH}_{2} \mathrm{O}-$ & 143 & 2.69 & 53 \\
\hline Ic & $\left(3-\mathrm{BrC}_{6} \mathrm{H}_{4}\right) \mathrm{CH}_{2} \mathrm{O}-$ & 19.7 & 0.576 & 34 \\
\hline Id & $\left(4-\mathrm{BrC}_{6} \mathrm{H}_{4}\right) \mathrm{CH}_{2} \mathrm{O}-$ & 2.90 & 0.172 & 17 \\
\hline le & $\left(3-\mathrm{BrC}_{6} \mathrm{H}_{4}\right) \mathrm{CH}_{2} \mathrm{O}-$ & 15.8 & 0.004 & 3,950 \\
\hline If & $\left(4-\mathrm{BrC}_{6} \mathrm{H}_{4}\right) \mathrm{CH}_{2} \mathrm{O}-$ & 6.26 & 0.011 & 569 \\
\hline
\end{tabular}

Note: ${ }^{2}$ The selectivity index is the selectivity for the MAO-B isoform and is given as the ratio of $I C_{50}\left(\right.$ MAO-A)/IC $C_{50}$ (MAO-B).

Abbreviations: MAO, monoamine oxidase; $\mathrm{Sl}$, selectivity index. also selective for MAO-B over the MAO-A isoform, with 1e (selectivity index $[\mathrm{SI}]=3,950$ ) possessing the highest selectivity of the series. Based on these results, the current study examines the MAO inhibitory properties of a series of 15 C5-substituted 2-acetylphenol analogs (2a-o) (Table 2). In the present study, the 2-acetylphenol analogs were first substituted on the C5 position with the benzyloxy, phenylethoxy, and phenylpropoxy moieties to yield compounds $2 \mathbf{a}-\mathbf{c}$. The MAO inhibitory properties of the benzyloxysubstituted 2-acetylphenol analog (2a) were further explored by substitution on the benzyloxy phenyl ring with halogens $(\mathrm{F}, \mathrm{Cl}, \mathrm{I})$ and alkyl groups $\left(\mathrm{CH}_{3}, \mathrm{CN}, \mathrm{CF}_{3}\right)$ to yield $\mathbf{2 d - m}$. The selection of the benzyloxy-substituted homologues for further investigation was based on the reports that the benzyloxy moiety is particularly suited for MAO inhibition by chromones ${ }^{19,20}$ and 3,4-dihydro-2(1H)-quinolinones. ${ }^{21}$ Literature also emphasizes the suitability of the benzyloxy substituent for MAO inhibition by coumarin derivatives. ${ }^{22,23}$ Furthermore, for these classes of compounds, halogen and alkyl substitution on the benzyloxy ring significantly

Table 2 The $\mathrm{IC}_{50}$ values for the inhibition of recombinant human MAO-A and MAO-B by 2-acetylphenol analogs $\mathbf{2 a - 0}$

\begin{tabular}{lllll}
\hline & & & \\
\end{tabular}

Notes: ${ }^{\mathrm{A}} \mathrm{All}$ values are expressed as the mean \pm SD of triplicate determinations. ${ }^{b} \mathrm{The}$ selectivity index is the selectivity for the MAO-B isoform and is given as the ratio of $\mathrm{IC}_{50}(\mathrm{MAO}-\mathrm{A}) / \mathrm{IC}_{50}$ (MAO-B). 'Value obtained from Harvey et al. ${ }^{29}{ }^{\mathrm{d}} \mathrm{V}$ alue obtained from Petzer et al. ${ }^{28}$

Abbreviations: MAO, monoamine oxidase; $\mathrm{Sl}$, selectivity index; SD, standard deviation. 
Table 3 The $\mathrm{IC}_{50}$ values for the inhibition of recombinant human MAO-A and MAO-B by $2^{\prime}, 4^{\prime}$-dihydroxyacetophenone (4) and 2-acetylphenol derivatives $\mathbf{3} \mathbf{a}-\mathbf{b}$

\begin{tabular}{|c|c|c|c|c|c|c|}
\hline \multirow[t]{2}{*}{ Compound } & \multirow[t]{2}{*}{$\begin{array}{l}\mathbf{R}^{\prime} \\
\end{array}$} & \multirow[t]{2}{*}{$\mathbf{R}^{2}$} & \multirow[t]{2}{*}{$\mathbf{R}^{3}$} & \multicolumn{2}{|l|}{$I C_{50}(\mu M)^{a}$} & \multirow[t]{2}{*}{$\mathbf{S} \mathbf{I}^{\mathrm{b}}$} \\
\hline & & & & MAO-A & MAO-B & \\
\hline 4 & $\mathrm{HO}-$ & HO- & $\mathrm{CH}_{3}-$ & $47.7 \pm 3.12$ & $39.7 \pm 5.03$ & 1.2 \\
\hline $3 a$ & $\mathrm{C}_{6} \mathrm{H}_{5} \mathrm{CH}_{2} \mathrm{O}-$ & $\mathrm{H}-$ & $\mathrm{CH}_{3}-$ & $19.5 \pm 2.47$ & $0.027 \pm 0.003$ & 722 \\
\hline $3 b$ & $\mathrm{C}_{6} \mathrm{H}_{5} \mathrm{CH}_{2} \mathrm{O}-$ & HO- & $\mathrm{C}_{2} \mathrm{H}_{5}-$ & $38.2 \pm 3.13$ & $0.004 \pm 0.001$ & 9,550 \\
\hline
\end{tabular}

enhances MAO inhibitory potency. Lastly, 2-acetylphenol analogs with the nonaromatic $n$-butoxy (2n) and $n$-heptyloxy (20) substituents were also included in this study. The effect on MAO inhibition of modification of the 2-acetylphenol nucleus was investigated with acetophenone derivative $\mathbf{3 a}$ and 2-propanoylphenol derivative $\mathbf{3 b}$ (Table 3).

\section{Materials and methods General}

Unless otherwise specified, all starting materials and reagents were obtained from Sigma-Aldrich (St Louis, MO, USA) and were used without further purification. Proton $\left({ }^{1} \mathrm{H}\right)$ and carbon $\left({ }^{13} \mathrm{C}\right)$ NMR spectra were recorded on a Bruker Avance III 600 spectrometer (Karlsruhe, Germany) at frequencies of $600 \mathrm{MHz}$ and $151 \mathrm{MHz}$, respectively. $\mathrm{CDCl}_{3}$ served as a NMR solvent, and chemical shifts are reported in parts per million ( $\delta$ ). Spin multiplicities are given as singlet (s), doublet (d), doublet of doublets (dd), triplet (t), quartet (q), pentet (p), or multiplet (m). High-resolution mass spectra were recorded on a Bruker micrOTOF-Q II mass spectrometer in atmospheric-pressure chemical ionization mode. Melting points were determined with a Büchi M-545 (Büchi Labortechnik, Flawil, Switzerland) melting point apparatus and are uncorrected. Thin layer chromatography was carried out using silica gel 60 (EMD Millipore, Billerica, MA, USA) with $\mathrm{UV}_{254}$ fluorescent indicator. The mobile phase consisted of ethyl acetate (one part) and petroleum ether (three parts). Fluorescence spectrophotometry was carried out with a Varian Cary Eclipse fluorescence spectrophotometer (Agilent Technologies, Santa Clara, CA, USA). Microsomes from insect cells expressing recombinant human MAO-A and MAO-B $(5 \mathrm{mg} / \mathrm{mL})$ were obtained from Sigma-Aldrich.
Kynuramine.2HBr was obtained from Sigma-Aldrich, and Slide-A-Lyzer dialysis cassettes with a molecular weight cut-off of 10,000 and a sample volume capacity of $0.5-3 \mathrm{~mL}$ were obtained from Thermo Fisher Scientific (Waltham, MA, USA).

\section{Chemistry}

\section{Procedure for the synthesis of $\mathrm{C} 5$-substituted}

2-acetylphenol analogs (2a-o and $\mathbf{3 a - b})$

To a mixture of $2^{\prime}, 4^{\prime}$-dihydroxyacetophenone $(4 ; 1 \mathrm{mmol})$ and anhydrous $\mathrm{K}_{2} \mathrm{CO}_{3}(2 \mathrm{mmol})$ in dry acetone $(15 \mathrm{~mL})$, the appropriate alkyl or arylalkyl bromide $(5 ; 1.1 \mathrm{mmol})$ was added. The mixture was stirred under reflux for 24 hours, cooled to room temperature, and filtered through a pad of Celite. The solvent was removed under reduced pressure, and the residues were recrystallized from ethanol. For the synthesis of $\mathbf{3 a}$ and $\mathbf{3 b}, 4^{\prime}$-hydroxyacetophenone (6) and $2^{\prime}, 4^{\prime}$-dihydroxypropiophenone (7), respectively, were reacted with benzyl bromide under the same conditions as above. Compounds $\mathbf{3 a}$ and $\mathbf{3 b}$ were purified by recrystallization from ethanol. ${ }^{19}$

\section{Enzymology} $\mathrm{IC}_{50}$ value determination

For the determination of $\mathrm{IC}_{50}$ values for MAO-A and MAO-B inhibition, the recombinant human enzymes were employed. Kynuramine, a nonselective MAO substrate, served as enzyme substrate. ${ }^{24}$ The concentration of 4-hydroxyquinoline, generated upon the oxidation of kynuramine by the MAOs, was measured by fluorescence spectrophotometry $\left(\lambda_{\mathrm{ex}}=310\right.$; $\lambda_{\mathrm{em}}=400 \mathrm{~nm}$ ). The protocol for these experiments has been reported in detail in a recent publication. ${ }^{25}$ Employing various inhibitor concentrations (spanning at least 3 orders of magnitude), sigmoidal curves were constructed by graphing residual enzyme activity versus the logarithm of inhibitor concentration. The $\mathrm{IC}_{50}$ values were determined in triplicate from these curves and are expressed as mean \pm standard deviation.

\section{Recovery of enzyme activity after dialysis}

The reversibility of MAO-B inhibition by $2 \mathbf{e}$ was investigated by measuring the recovery of MAO-B activity after mixtures containing the enzyme and test inhibitor were dialyzed. The protocol for these experiments has been reported in detail in recent publications. ${ }^{25,26}$ All reactions were carried out in triplicate, and the residual enzyme catalytic rates (as percentage of the negative control value) were expressed as mean \pm standard deviation. 
The construction of Lineweaver-Burk plots and $K_{i}$ value calculations

The mode of MAO-B inhibition by $\mathbf{2 e}$ was investigated by constructing a set of six Lineweaver-Burk plots. The first plot was constructed in the absence of inhibitor while the remaining five plots were constructed in the presence of different concentrations of the test inhibitor. The inhibitor concentrations that were selected were $1 / 4 \times \mathrm{IC}_{50}, 1 / 2 \times \mathrm{IC}_{50}, 3 / 4 \times \mathrm{IC}_{50}, 1 \times \mathrm{IC}_{50}$, and $11 / 4 \times \mathrm{IC}_{50}$. Kynuramine was used at concentrations of $15-250 \mu \mathrm{M}$. The protocol for these experiments has been reported in detail in recent publications. ${ }^{25,26} \mathrm{~A} K_{i}$ value for the inhibition of MAO-B was estimated from a plot of the slopes of the Lineweaver-Burk plots versus inhibitor concentration, where the x-axis intercept equals $-K_{i}$. The $K_{i}$ value may also be estimated by global (shared) fitting of the inhibition data directly to the Michaelis-Menten equation using the Prism 5 software package (GraphPad, San Diego, CA, USA).

\section{Results and discussion}

\section{Chemistry}

The C5-substituted 2-acetylphenol analogs, 2a-0, were synthesized in low to good yields (39\%-93\%) by reacting $2^{\prime}, 4^{\prime}-$ dihydroxyacetophenone (4) with the appropriate alkyl or arylalkyl bromide (5) in the presence of $\mathrm{K}_{2} \mathrm{CO}_{3}$ in acetone (Figure 1). For the synthesis of $\mathbf{3} \mathbf{a}$ and $\mathbf{3} \mathbf{b}, 4^{\prime}$-hydroxyacetophenone (6) and 2',4'-dihydroxypropiophenone (7), respectively, were reacted with benzyl bromide under the same conditions as earlier. In each instance, the structures and purities of the target compounds were verified by ${ }^{1} \mathrm{H}$ NMR, ${ }^{13} \mathrm{C}$ NMR, and mass spectrometry as cited in the supplementary materials.

\section{Potencies of MAO inhibition}

The 2-acetylphenol analogs were evaluated as inhibitors of the recombinant human MAO-A and MAO-B enzymes, and
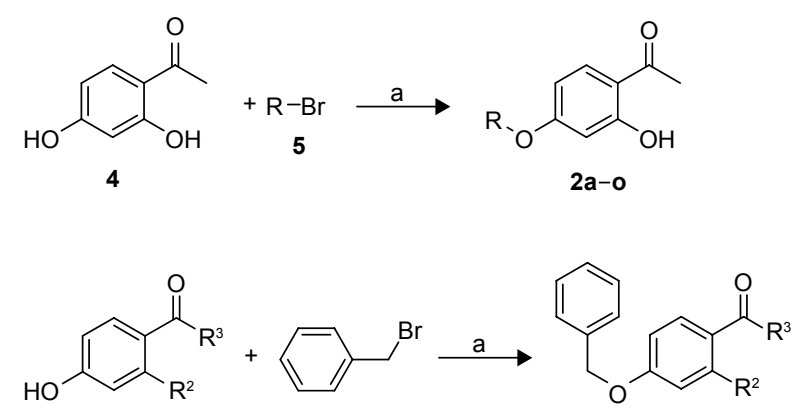

6: $\mathrm{R}^{2}=\mathrm{H} ; \mathrm{R}^{3}=\mathrm{CH}_{3}$

7: $\mathrm{R}^{2}=\mathrm{OH} ; \mathrm{R}^{3}=\mathrm{C}_{2} \mathrm{H}_{5}$

3a: $\mathrm{R}^{2}=\mathrm{H} ; \mathrm{R}^{3}=\mathrm{CH}_{3}$ 3b: $\mathrm{R}^{2}=\mathrm{OH} ; \mathrm{R}^{3}=\mathrm{C}_{2} \mathrm{H}_{5}$

Figure I Synthetic route to the 2-acetylphenol analogs $\mathbf{2 a - o}$ and $\mathbf{3} \mathbf{a}-\mathbf{b}$. Note: Reagents and conditions: (a) acetone, $\mathrm{K}_{2} \mathrm{CO}_{3}$, reflux. the inhibition potencies were expressed as the corresponding $\mathrm{IC}_{50}$ values. ${ }^{24}$ To measure the catalytic activities of the MAO enzymes, the mixed MAO-A/B substrate, kynuramine, was used. Kynuramine is oxidized by the MAOs to yield 4-hydroxyquinoline as final product. This metabolite fluoresces in alkaline media and may thus be conveniently quantified by fluorescence spectrophotometry. ${ }^{27}$ Using the appropriate control reactions, it was determined that none of the 2-acetylphenol analogs investigated here fluoresce under the specific assay conditions and thus do not interfere with the fluorescence measurement of 4-hydroxyquinoline. $\mathrm{IC}_{50}$ values were estimated from sigmoidal plots of the residual MAO activities recorded in the presence of the test inhibitors versus the logarithm of inhibitor concentration.

The human MAO inhibitory properties of the C5substituted 2-acetylphenol analogs are shown in Tables 2 and 3. As evident from the SI values (SI $>30$ ), all of the 2-acetylphenol analogs $(\mathbf{2} \mathbf{a}-\mathbf{0}, \mathbf{3 a}, \mathbf{b})$ are selective inhibitors of MAO-B. Among these, seven compounds (of 17) exhibited $\mathrm{IC}_{50}$ values $<0.01 \mu \mathrm{M}$ for the inhibition of MAO-B. These compounds (2a, $\mathbf{2} \mathbf{d}-\mathbf{f}, \mathbf{2} \mathbf{l}, \mathbf{m}, \mathbf{3 b})$ may be viewed as exceptionally potent MAO-B inhibitors and possess higher potencies than the reference MAO-B inhibitor, lazabemide $\left(\mathrm{IC}_{50}=0.091 \mu \mathrm{M}\right) .{ }^{28}$ With $\mathrm{IC}_{50}$ values in the nanomolar range $(0.0013-0.157 \mu \mathrm{M})$, all of the 2-acetylphenol analogs may, however, be viewed as potent MAO-B inhibitors. Among the high potency inhibitors $\left(\mathrm{IC}_{50}<0.01 \mu \mathrm{M}\right)$, compounds $\mathbf{2 d}, \mathbf{2 f}$, and $\mathbf{3 b}$ may be highlighted. These compounds exhibit SI values $>9,550$ and are thus the most selective MAO-B inhibitors of the present study. The finding that $\mathrm{C} 5$-substituted 2-acetylphenol analogs are potent and selective MAO-B inhibitors is in accordance to the previous study, which has shown that substitution on the $\mathrm{C} 5$ position of 2-acetylphenol (eg, 1e and 1f) yields selective MAO-B inhibitors. The $\mathrm{IC}_{50}$ values recorded for $\mathbf{1 e}$ and $\mathbf{1 f}$ are in the same range as those of the most potent inhibitors of the present study (Table 1). ${ }^{19}$

The C5-substituted 2-acetylphenol analogs (2a-o, 3a, b) also inhibited human MAO-A. With $\mathrm{IC}_{50}$ values in the micromolar range $(1.64-50.7 \mu \mathrm{M})$, these compounds are, relative to their MAO-B inhibition potencies, weak MAO-A inhibitors. Also, compared to the reference MAO-A inhibitor, methylene blue $\left(\mathrm{IC}_{50}=0.07 \mu \mathrm{M}\right)$, the 2 -acetylphenol analogs are at least 23-fold weaker as MAO-A inhibitors. ${ }^{29}$ The finding that $\mathrm{C} 5$-substituted 2-acetylphenol analogs are relatively weak MAO-A inhibitors is in agreement to the previous study, which has shown that $\mathbf{1 e}$ and $\mathbf{1 f}$ are weak MAO-A inhibitors with $\mathrm{IC}_{50}$ values in the same range as those of the C5-substituted 2-acetylphenol analogs of the present study (Table 1). ${ }^{19}$ 


\section{Structure-activity relationships for MAO inhibition}

From the inhibition data, some structure-activity relationships (SARs) may be derived. The 2-acetylphenol analogs with the nonaromatic $n$-butoxy and $n$-heptyloxy substituents, compounds $2 \mathbf{n}\left(\mathrm{IC}_{50}=0.103 \mu \mathrm{M}\right)$ and $2 \mathbf{o}\left(\mathrm{IC}_{50}=0.156 \mu \mathrm{M}\right)$, respectively, are among the three weakest MAO-B inhibitors of the present study. This shows that these substituents may be less suitable for MAO-B inhibition than, for example, the benzyloxy-derived substituents (eg, 2a, 2d-m), which yield compounds with $\mathrm{IC}_{50}$ values of $0.0013-0.054 \mu \mathrm{M}$. It is noteworthy that substitution with the benzyloxy moiety (2a) yields more potent MAO-B inhibition than substitution with the phenylethoxy (2b) and phenylpropoxy (2c) moieties. This suggests that, among these three substituents, the benzyloxy moiety is most suitable for MAO-B inhibition by 2-acetylphenol analogs. Among the benzyloxy-derived compounds (2a, $\mathbf{2} \mathbf{d}-\mathbf{m})$, no SARs for the inhibition of MAO-B are apparent, and all compounds are potent MAO-B inhibitors $\left(\mathrm{IC}_{50}<0.054 \mu \mathrm{M}\right)$. The effect of modification of the 2-acetylphenol nucleus was investigated with acetophenone derivative 3a and 2-propanoylphenol derivative 3b. Removal of the phenolic hydroxyl to yield 3a $\left(\mathrm{IC}_{50}\right.$ $=0.027 \mu \mathrm{M})$ resulted is a small loss of MAO-B inhibition activity when compared to its 2-acetylphenol homologue $\mathbf{2 a}$ $\left(\mathrm{IC}_{50}=0.007 \mu \mathrm{M}\right)$, while the 2-propanoylphenol derivative 3b $\left(\mathrm{IC}_{50}=0.004 \mu \mathrm{M}\right)$ was approximately equipotent to $\mathbf{2 a}$. It may thus be concluded that small structural modifications to the 2-acetylphenol moiety are well tolerated and does not necessarily abolish MAO-B inhibition activity. Interestingly, $\mathbf{3 a}$ and $\mathbf{3 b}$ are significantly weaker MAO-A inhibitors than the corresponding 2-acetylphenol homologue $\mathbf{2 a}$, which suggests that removal of the phenolic hydroxyl (to yield 3a) and replacing the acetyl group with propanoyl (to yield $\mathbf{3 b}$ ) may improve selectivity of inhibition for MAO-B. This is exemplified by $\mathbf{3 b}$, an equipotent MAO-B inhibitor to $\mathbf{2} \mathbf{a}$, but with improved selectivity. Lastly, it is interesting to note that among the three most potent MAO-A inhibitors, two are the nitrile-containing compounds $2 \mathbf{k}\left(\mathrm{IC}_{50}=1.64 \mu \mathrm{M}\right)$ and $\mathbf{2 l}$ $\left(\mathrm{IC}_{50}=2.72 \mu \mathrm{M}\right)$. This suggests that the nitrile group enhances MAO-A inhibition, an observation for which the molecular basis is not readily apparent.

As mentioned earlier, a previous study has shown that substitution on the $\mathrm{C} 5$ position of 2-acetylphenol (eg, 1e and 1f) is particularly favorable for high potency MAO-B inhibition and yields higher potency inhibitors than substitution on C4 (1c, 1d) and C3 (1a, 1b). ${ }^{19}$ To further evaluate the importance of the $\mathrm{C} 5$ substituent for the inhibition of
MAO-B, 2', 4'-dihydroxyacetophenone (4) was evaluated as an inhibitor of the human MAOs. The results document that 4 is a weak MAO-B inhibitor with an $\mathrm{IC}_{50}$ value of $39.7 \mu \mathrm{M}$. Compound $\mathbf{4}$ is thus 250 -fold weaker as a MAO-B inhibitor than the weakest inhibitor of the present series, compound $\mathbf{2 b}$ $\left(\mathrm{IC}_{50}=0.157 \mu \mathrm{M}\right)$. This demonstrates that an appropriate $\mathrm{C} 5$ substituent is necessary for high potency MAO-B inhibition by 2-acetylphenol analogs. Interestingly, $4\left(\mathrm{IC}_{50}=47.7 \mu \mathrm{M}\right)$ is a superior MAO-A inhibitor than some of the $\mathrm{C} 5$-substituted 2-acetylphenol analogs (eg, 2d and 2o).

\section{Reversibility of MAO-B inhibition}

Employing dialysis, the present study also investigated the reversibility of MAO-B inhibition by one representative inhibitor, compound $\mathbf{2 e}\left(\mathrm{IC}_{50}=0.003 \mu \mathrm{M}\right)$. The reversibility of inhibition was examined by measuring the recovery of enzyme activity after dialysis of enzyme-inhibitor mixtures. ${ }^{26}$ Since none of the 2-acetylphenol analogs were potent MAO-A inhibitors, only the reversibility of MAO-B inhibition was further investigated. MAO-B and $\mathbf{2 e}$, at an inhibitor concentration of $4 \times \mathrm{IC}_{50}$, was incubated for 15 minutes, dialyzed for 24 hours, and the residual enzyme activity was subsequently measured. The results are given in Figure 2, which show that the MAO-B inhibition by $\mathbf{2} \mathbf{e}$ is only partially reversed after 24 hours of dialysis, with the catalytic activity recovering to $52 \%$ of the negative control value (activity in the absence of inhibitor). For reversible inhibition, the enzyme activity is, however, expected to recover to $100 \%$ after dialysis. The enzyme activity of undialyzed mixtures of MAO-B and $\mathbf{2} \mathbf{e}$ is $30 \%$ of the control value. As positive control, the irreversible inhibitor, $(R)$-deprenyl, was similarly incubated with MAO-B and dialyzed. As expected for irreversible inhibition, enzyme

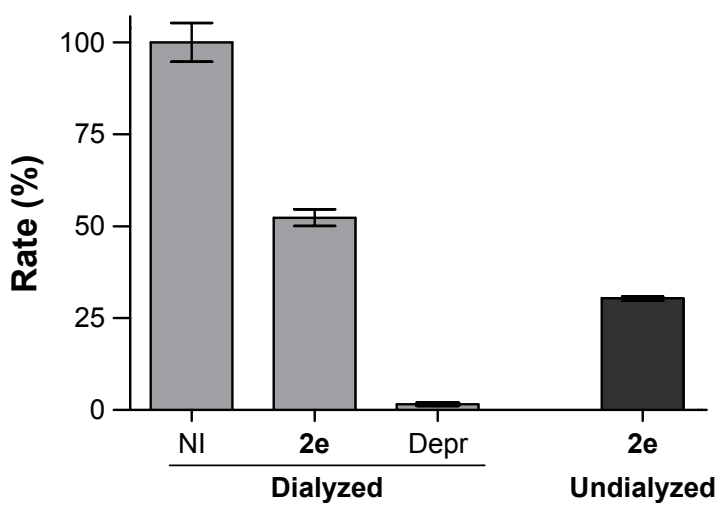

Figure 2 Reversibility of the inhibition of MAO-B by $2 \mathrm{e}$

Notes: MAO-B was preincubated in the absence of inhibitor ( $\mathrm{NI}$ - dialyzed), in the presence of $2 \mathbf{e}(\mathbf{2} \mathbf{e}-$ dialyzed) and in the presence of the irreversible inhibitor, (R)-deprenyl (depr - dialyzed). These mixtures were subsequently dialyzed for 24 hours and the residual enzyme activity was measured. For comparison, the residual activity of undialyzed mixtures of MAO-B with $\mathbf{2 e}$ is also shown ( $\mathbf{2} \mathbf{e}-$ undialyzed). Abbreviations: MAO, monoamine oxidase; $h$, hour. 
activity is not recovered, with only $1.6 \%$ activity remaining. While the molecular basis for the observation that MAO-B inhibition is only partially reversed by dialysis, is not known, high potency MAO-B inhibitors such as 2e may act by tight binding. Potential tight binding of inhibitors to MAO-B has been reported on a number of occasions, ${ }^{30-33}$ and partial recovery of MAO-B activity following dialysis of enzymeinhibitor mixtures has previously been reported. ${ }^{25}$ Further investigation is necessary to clarify this point.

\section{Competitive inhibition}

To gain further insight into the mode of MAO-B inhibition by 2-acetylphenols, a set of Lineweaver-Burk graphs were constructed for the inhibition of MAO-B by the representative inhibitor, 2e. The set consisted of six graphs, each constructed by measuring MAO-B catalytic rate at eight different kynuramine concentrations $(15-250 \mu \mathrm{M})$. The first Lineweaver-Burk graph was constructed in the absence of inhibitor, while the remaining five graphs were constructed in the presence of different concentrations of 2e. As shown in Figure 3 the set of Lineweaver-Burk graphs is indicative of competitive inhibition since the lines are linear and intersect on the $y$ axis. This suggests that $\mathbf{2} \mathbf{e}$ is a competitive inhibitor of human MAO-B. From a replot of the slopes of the Lineweaver-Burk plots versus the concentration of $\mathbf{2 e}$, a $K_{i}$ value of $0.0038 \mu \mathrm{M}$ is estimated for the inhibition of MAO-B. Global (shared) fitting of the inhibition data directly to the Michaelis-Menten equation yielded a similar $K_{i}$ value of $0.0039 \pm 0.00035 \mu \mathrm{M}\left(r^{2}=0.99\right)$.

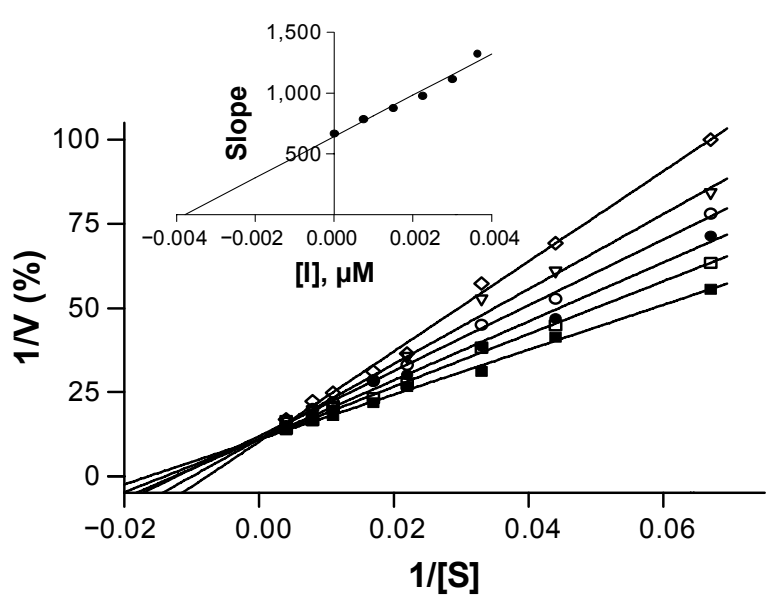

Figure 3 Lineweaver-Burk graphs of human MAO-B activities in the absence (filled squares) and presence of various concentrations of $2 \mathbf{e}$.

Notes: The concentrations of $2 \mathrm{e}$ used were equal to $\mathrm{I} / 4 \times \mathrm{IC}_{50}$ (open squares), $\mathrm{I} / 2 \times \mathrm{IC}_{50}$ (filled circles), $3 / 4 \times \mathrm{IC}_{50}$ (open circles), I $\times \mathrm{IC}_{50}$ (triangles), I I/4× IC (diamonds). The insert is a graph of the slopes of the Lineweaver-Burk graphs versus inhibitor concentration.

Abbreviation: MAO, monoamine oxidase.

\section{Conclusion}

In conclusion, this study shows that C5-substituted 2-acetylphenol analogs are highly potent MAO-B inhibitors with seven compounds (of 17) exhibiting $\mathrm{IC}_{50}$ values $<0.01 \mu \mathrm{M}$. The 2 -acetylphenol analogs also are selective for the MAO-B isoform as exemplified by compounds $\mathbf{2 d}, \mathbf{2 f}$, and $\mathbf{3 b}$, which possess SI values $>9,550$. With relatively weak MAO-A inhibitory potencies $\left(\mathrm{IC}_{50}>17.7 \mu \mathrm{M}\right)$, these three compounds may be suitable candidates for the development of MAO-B selective inhibitors for Parkinson's disease. Such compounds are unlikely to provoke tyramine induced adverse effects as a result of MAO-A inhibition. Furthermore, the possibility that high potency 2-acetylphenol analogs bind tightly to MAO-B is not of concern since clinically used irreversible MAO-B inhibitors are reported to possess excellent safety profiles. ${ }^{17}$ Further examination of the physicochemical, biochemical, and pharmacokinetic properties is necessary to determine if promising 2-acetylphenols may be acceptable in vivo drugs.

\section{Acknowledgments}

The NMR and MS spectra were recorded by André Joubert and Johan Jordaan of the SASOL Centre for Chemistry, North-West University. This work is based on the research supported in part by the Medical Research Council and National Research Foundation of South Africa (Grant specific unique reference numbers 85642, 80647, and 80637). The Grantholders acknowledge that opinions, findings and conclusions, or recommendations expressed in any publication generated by the NRF supported research are that of the authors and that the NRF accepts no liability whatsoever in this regard.

\section{Disclosure}

The authors report no conflicts of interest in this work.

\section{References}

1. Olanow CW, Stern MB, Sethi K. The scientific and clinical basis for the treatment of Parkinson disease (2009). Neurology. 2009;72(21 suppl 4): S1-S136.

2. Carlsson A. Treatment of Parkinson's with L-dopa. The early discovery phase, and a comment on current problems. J Neural Transm. 2002; 109(5-6): 777-787.

3. Pedrosa DJ, Timmermann L. Review: management of Parkinson's disease. Neuropsychiatr Dis Treat. 2013;9:321-340.

4. Talati R, Baker WL, Patel AA, Reinhart K, Coleman CI. Adding a dopamine agonist to preexisting levodopa therapy vs levodopa therapy alone in advanced Parkinson's disease: a meta analysis. Int J Clin Pract. 2009;63(4):613-623.

5. Fahn S, Oakes D, Shoulson I, et al; Parkinson Study Group. Levodopa and the progression of Parkinson's disease. N Engl J Med. 2004;351(24): $2498-2508$. 
6. Youdim MB, Edmondson D, Tipton KF. The therapeutic potential of monoamine oxidase inhibitors. Nat Rev Neurosci. 2006;7(4): 295-309.

7. Youdim MB, Bakhle YS. Monoamine oxidase: isoforms and inhibitors in Parkinson's disease and depressive illness. Br J Pharmacol. 2006;147(suppl 1):S287-S296.

8. Shoulson I, Oakes D, Fahn S, et al; Parkinson Study Group. Impact of sustained deprenyl (selegiline) in levodopa-treated Parkinson's disease: a randomized placebo-controlled extension of the deprenyl and tocopherol antioxidative therapy of parkinsonism trial. Ann Neurol. 2002;51(5):604-612.

9. Fernandez HH, Chen JJ. Monoamine oxidase-B inhibition in the treatment of Parkinson's disease. Pharmacotherapy. 2007;27(12 pt 2): $174 \mathrm{~S}-185 \mathrm{~S}$.

10. Finberg JP, Wang J, Bankiewicz K, Harvey-White J, Kopin IJ, Goldstein DS. Increased striatal dopamine production from L-dopa following selective inhibition of monoamine oxidase B by $\mathrm{R}(+)-\mathrm{N}-$ propargyl-1-aminoindan (rasagiline) in the monkey. J Neural Transm Suppl. 1998;52:279-285.

11. Pålhagen S, Heinonen EH, Hägglund J, et al. Selegiline delays the onset of disability in de novo parkinsonian patients. Swedish Parkinson Study Group. Neurology. 1998;51(2):520-525.

12. Schwartz TL. A neuroscientific update on monoamine oxidase and its inhibitors. CNS Spectr. 2013;18(suppl 1):25-32.

13. Lum CT, Stahl SM. Opportunities for reversible inhibitors of monoamine oxidase-A (RIMAs) in the treatment of depression. CNS Spectr. 2012;17(3):107-120.

14. Da Prada M, Zürcher G, Wüthrich I, Haefely WE. On tyramine, food, beverages and the reversible MAO inhibitor moclobemide. J Neural Transm Suppl. 1988;26:31-56.

15. Bonnet U. Moclobemide: therapeutic use and clinical studies. CNS Drug Rev. 2003;9(1):97-140.

16. Provost JC, Funck-Brentano C, Rovei V, D'Estanque J, Ego D, Jaillon P. Pharmacokinetic and pharmacodynamic interaction between toloxatone, a new reversible monoamine oxidase-A inhibitor, and oral tyramine in healthy subjects. Clin Pharmacol Ther. 1992;52(4):384-393.

17. Pae CU, Bodkin JA, Portland KB, Thase ME, Patkar AA. Safety of selegiline transdermal system in clinical practice: analysis of adverse events from postmarketing exposures. J Clin Psychiatry. 2012;73(5): 661-668.

18. Carradori S, Petzer JP. Novel monoamine oxidase inhibitors: a patent review (2012-2014). Expert Opin Ther Pat. 2015;25(1):91-110.

19. Legoabe LJ, Petzer A, Petzer JP. Selected chromone derivatives as inhibitors of monoamine oxidase. Bioorg Med Chem Lett. 2012;22(17): 5480-5484.

20. Legoabe LJ, Petzer A, Petzer JP. Inhibition of monoamine oxidase by selected C6-substituted chromone derivatives. Eur J Med Chem. 2012; 49:343-353.
21. Meiring L, Petzer JP, Petzer A. Inhibition of monoamine oxidase by 3,4-dihydro-2(1H)-quinolinone derivatives. Bioorg Med Chem Lett. 2013;23(20):5498-5502.

22. Secci D, Carradori S, Bolasco A, et al. Synthesis and selective human monoamine oxidase inhibition of 3-carbonyl, 3-acyl, and 3-carboxyhydrazido coumarin derivatives. Eur J Med Chem. 2011;46(10): 4846-4852.

23. Chimenti F, Secci D, Bolasco A, et al. Synthesis, molecular modeling, and selective inhibitory activity against human monoamine oxidases of 3-carboxamido-7-substituted coumarins. J Med Chem. 2009;52(7): 1935-1942.

24. Novaroli L, Reist M, Favre E, Carotti A, Catto M, Carrupt PA. Human recombinant monoamine oxidase $\mathrm{B}$ as reliable and efficient enzyme source for inhibitor screening. Bioorg Med Chem. 2005;13(22): 6212-6217.

25. Legoabe LJ, Petzer A, Petzer JP. $\alpha$-Tetralone derivatives as inhibitors of monoamine oxidase. Bioorg Med Chem Lett. 2014;24(12): 2758-2763.

26. Petzer A, Pienaar A, Petzer JP. The interactions of caffeine with monoamine oxidase. Life Sci. 2013;93(7):283-287.

27. Strydom B, Malan SF, Castagnoli N Jr, Bergh JJ, Petzer JP. Inhibition of monoamine oxidase by 8-benzyloxycaffeine analogues. Bioorg Med Chem. 2010;18(3):1018-1028.

28. Petzer A, Pienaar A, Petzer JP. The inhibition of monoamine oxidase by esomeprazole. Drug Res (Stuttg). 2013;63(9):462-467.

29. Harvey BH, Duvenhage I, Viljoen F, et al. Role of monoamine oxidase, nitric oxide synthase and regional brain monoamines in the antidepressant-like effects of methylene blue and selected structural analogues. Biochem Pharmacol. 2010;80(10):1580-1591.

30. Gaspar A, Silva T, Yáñez M, et al. Chromone, a privileged scaffold for the development of monoamine oxidase inhibitors. J Med Chem. 2011; 54(14):5165-5173.

31. Gaspar A, Reis J, Fonseca A, et al. Chromone 3-phenylcarboxamides as potent and selective MAO-B inhibitors. Bioorg Med Chem Lett. 2011 21(2):707-709.

32. Krueger MJ, Mazouz F, Ramsay RR, Milcent R, Singer TP. Dramatic species differences in the susceptibility of monoamine oxidase B to a group of powerful inhibitors. Biochem Biophys Res Commun. 1995;206(2):556-562.

33. Mazouz F, Gueddari S, Burstein C, Mansuy D, Milcent R. 5-[4(Benzyloxy)phenyl]-1,3,4-oxadiazol-2(3H)-one derivatives and related analogues: new reversible, highly potent, and selective monamine oxidase type B inhibitors. J Med Chem. 1993;36(9):1157-1167. 


\section{Supplementary materials 2-Acetyl-5-benzyloxyphenol (2a)}

The title compound (clear crystals) was prepared in a yield of 93\%: $\mathrm{mp} 103.1^{\circ} \mathrm{C}-103.4^{\circ} \mathrm{C}$ (ethanol), lit. $\mathrm{mp} 101^{\circ} \mathrm{C}-103^{\circ} \mathrm{C} .{ }^{1}$ ${ }^{1} \mathrm{H}$ NMR $\left(600 \mathrm{MHz}, \mathrm{CDCl}_{3}\right) \delta 12.71(\mathrm{~s}, 1 \mathrm{H}), 7.62(\mathrm{~d}$, $J=8.7 \mathrm{~Hz}, 1 \mathrm{H}), 7.42-7.35(\mathrm{~m}, 4 \mathrm{H}), 7.24(\mathrm{~s}, 1 \mathrm{H}), 6.52-6.47$ (m, 2H), 5.08 (s, 2H), $2.54(\mathrm{~s}, 3 \mathrm{H}) ;{ }^{13} \mathrm{C}$ NMR $(151 \mathrm{MHz}$, $\left.\mathrm{CDCl}_{3}\right) \delta 202.55,165.13,135.81,132.31,128.66,128.27$, 127.49, 114.03, 108.09, 101.82, 101.81, 70.16, 26.20; APCI-HRMS m/z: calcd for $\mathrm{C}_{15} \mathrm{H}_{15} \mathrm{O}_{3}\left(\mathrm{MH}^{+}\right), 243.1016$, found 243.1001.

\section{2-Acetyl-5-(2-phenylethoxy)phenol (2b)}

The title compound (white crystals) was prepared in a yield of $51 \%$ : $\mathrm{mp} 71.0^{\circ} \mathrm{C}-72.3^{\circ} \mathrm{C}$ (ethanol), lit. mp $69^{\circ} \mathrm{C} .{ }^{2}{ }^{1} \mathrm{H}$ $\operatorname{NMR}\left(600 \mathrm{MHz}, \mathrm{CDCl}_{3}\right) \delta 12.71(\mathrm{~s}, 1 \mathrm{H}), 7.60(\mathrm{~d}, J=8.8 \mathrm{~Hz}$, 1H), 7.31 (t, $J=7.5 \mathrm{~Hz}, 2 \mathrm{H}), 7.28-7.22(\mathrm{~m}, 3 \mathrm{H}), 6.44-6.38$ (m, 2H), 4.19 (t, $J=7.0 \mathrm{~Hz}, 2 \mathrm{H}), 3.09$ (t, $J=7.0 \mathrm{~Hz}, 2 \mathrm{H}$ ), $2.53(\mathrm{~s}, 3 \mathrm{H}) ;{ }^{13} \mathrm{C} \mathrm{NMR}\left(151 \mathrm{MHz}, \mathrm{CDCl}_{3}\right) \delta 202.50,165.26$, $165.15,137.63,132.27,128.92,128.53,126.64,107.85$, 101.40, 101.39, 68.84, 35.40, 26.18; APCI-HRMS m/z: calcd for $\mathrm{C}_{16} \mathrm{H}_{17} \mathrm{O}_{3}\left(\mathrm{MH}^{+}\right), 257.1172$, found 257.1153 .

\section{2-Acetyl-5-(3-phenylpropoxy)phenol (2c)}

The title compound (clear flakes) was prepared in a yield of $61 \%$ : $\mathrm{mp} 76.4^{\circ} \mathrm{C}-78.1^{\circ} \mathrm{C}$ (ethanol), lit. $\mathrm{mp} 75^{\circ} \mathrm{C}-77^{\circ} \mathrm{C} .{ }^{2}$ ${ }^{1} \mathrm{H}$ NMR $\left(600 \mathrm{MHz}, \mathrm{CDCl}_{3}\right) \delta 12.73(\mathrm{~s}, 1 \mathrm{H}), 7.61$ (d, $J=8.9$ $\mathrm{Hz}, 1 \mathrm{H}), 7.31-7.25$ (m, 2H), 7.19 (d, $J=7.8 \mathrm{~Hz}, 3 \mathrm{H}), 6.43$ (dd, $J=8.9,2.5 \mathrm{~Hz}, 1 \mathrm{H}), 6.37$ (d, $J=2.5 \mathrm{~Hz}, 1 \mathrm{H}), 3.97$ (t, $J=6.3 \mathrm{~Hz}, 2 \mathrm{H}), 2.82-2.76(\mathrm{~m}, 2 \mathrm{H}), 2.54(\mathrm{~s}, 3 \mathrm{H}), 2.14-2.07$ $(\mathrm{m}, 2 \mathrm{H}) ;{ }^{13} \mathrm{C}$ NMR $\left(151 \mathrm{MHz}, \mathrm{CDCl}_{3}\right) \delta 202.49,165.54$, $165.18,141.05,132.25,128.45,126.03,113.79,107.92$, $101.30,101.29,67.19,31.97,30.45,26.18$; APCIHRMS m/z: calcd for $\mathrm{C}_{17} \mathrm{H}_{19} \mathrm{O}_{3}\left(\mathrm{MH}^{+}\right), 271.1329$, found 271.1326 .

\section{2-Acetyl-5-(3-fluorobenzyloxy)phenol (2d)}

The title compound (clear crystals) was prepared in a yield of $52 \%$ : $\mathrm{mp} 108.5^{\circ} \mathrm{C}-112.3^{\circ} \mathrm{C}$ (ethanol), lit. $\mathrm{mp}$ $108^{\circ} \mathrm{C}-109^{\circ} \mathrm{C} .{ }^{3}{ }^{1} \mathrm{H}$ NMR $\left(600 \mathrm{MHz}, \mathrm{CDCl}_{3}\right) \delta 12.72$ (s, 1H), $7.63(\mathrm{~d}, J=8.9 \mathrm{~Hz}, 1 \mathrm{H}), 7.34(\mathrm{q}, J=7.7 \mathrm{~Hz}, 1 \mathrm{H})$, $7.14(\mathrm{dd}, J=26.5,8.5 \mathrm{~Hz}, 2 \mathrm{H}), 7.01(\mathrm{t}, J=9.1 \mathrm{~Hz}, 1 \mathrm{H})$, 6.52-6.44 (m, 2H), 5.07 (s, 2H), 2.54 (s, 3H); ${ }^{13} \mathrm{C}$ NMR (151 $\left.\mathrm{MHz}, \mathrm{CDCl}_{3}\right) \delta 202.62,165.10,164.75,163.75,162.12$, $138.41,138.36,132.39,130.28,130.23,122.73,122.71$, $115.21,115.07,114.29,114.19,114.15,108.02,101.83$, 101.81, 69.27, 69.25, 26.24; APCI-HRMS m/z: calcd for $\mathrm{C}_{15} \mathrm{H}_{14} \mathrm{FO}_{3}\left(\mathrm{MH}^{+}\right), 261.0921$, found 261.0942.
2-Acetyl-5-(4-fluorobenzyloxy)phenol (2e)

The title compound (clear crystals) was prepared in a yield of $53 \%$ : mp $112.4^{\circ} \mathrm{C}-113.9^{\circ} \mathrm{C}$ (ethanol). ${ }^{1} \mathrm{H}$ NMR (600 $\left.\mathrm{MHz}, \mathrm{CDCl}_{3}\right) \delta 12.72(\mathrm{~s}, 1 \mathrm{H}), 7.62(\mathrm{~d}, J=8.8 \mathrm{~Hz}, 1 \mathrm{H}), 7.37$ (dd, $J=8.4,5.4 \mathrm{~Hz}, 2 \mathrm{H}), 7.06$ (t, $J=8.6 \mathrm{~Hz}, 2 \mathrm{H}), 6.51-6.45$ (m, 2H), 5.03 (s, 2H), $2.54(\mathrm{~s}, 3 \mathrm{H}) ;{ }^{13} \mathrm{C}$ NMR $(151 \mathrm{MHz}$, $\left.\mathrm{CDCl}_{3}\right) \delta 202.60,165.13,164.92,163.45,161.81,132.36$, $131.60,131.58,129.45,129.40,115.70,115.56,114.12$, 108.07, 101.78, 101.77, 69.49, 26.24; APCI-HRMS m/z: calcd for $\mathrm{C}_{15} \mathrm{H}_{14} \mathrm{FO}_{3}\left(\mathrm{MH}^{+}\right), 261.0921$, found 261.0932.

\section{2-Acetyl-5-(3-chlorobenzyloxy)phenol (2f)}

The title compound (off-white crystals) was prepared in a yield of $67 \%$ : $\mathrm{mp} 127.1^{\circ} \mathrm{C}-129.1^{\circ} \mathrm{C}$ (ethanol), lit. $\mathrm{mp}$ $127^{\circ} \mathrm{C}-128^{\circ} \mathrm{C} .{ }^{3}{ }^{1} \mathrm{H}$ NMR (600 MHz, $\mathrm{CDCl}_{3}$ ) $\delta 12.72$ (s, 1H), 7.63 (d, $J=8.9 \mathrm{~Hz}, 1 \mathrm{H}), 7.40(\mathrm{~s}, 1 \mathrm{H}), 7.32-7.22$ (m, 3H), 6.49 (dd, $J=8.9 \mathrm{~Hz}, 1 \mathrm{H}), 6.45$ (d, $J=2.5 \mathrm{~Hz}, 1 \mathrm{H})$, $5.04(\mathrm{~s}, 2 \mathrm{H}), 2.54(\mathrm{~s}, 3 \mathrm{H}) ;{ }^{13} \mathrm{C} \mathrm{NMR}\left(151 \mathrm{MHz}, \mathrm{CDCl}_{3}\right)$ $\delta$ 202.63, 165.11, 164.74, 137.88, 134.61, 132.40, 129.96, 128.41, 127.41, 125.35, 114.22, 108.02, 101.82, 69.24, 26.25; APCI-HRMS m/z: calcd for $\mathrm{C}_{15} \mathrm{H}_{14} \mathrm{ClO}_{3}\left(\mathrm{MH}^{+}\right), 277.0626$, found 277.0619 .

\section{2-Acetyl-5-(4-chlorobenzyloxy)phenol (2g)}

The title compound (off-white crystals) was prepared in a yield of $62 \%$ : mp $102.2^{\circ} \mathrm{C}-102.5^{\circ} \mathrm{C}$ (ethanol). ${ }^{1} \mathrm{H}$ NMR $\left(600 \mathrm{MHz}, \mathrm{CDCl}_{3}\right) \delta 12.71(\mathrm{~s}, 1 \mathrm{H}), 7.62(\mathrm{~d}, J=8.9 \mathrm{~Hz}, 1 \mathrm{H})$, 7.37-7.30 (m, 4H), 6.50-6.43 (m, 2H), $5.03(\mathrm{~s}, 2 \mathrm{H}), 2.54$ $(\mathrm{s}, 3 \mathrm{H}) ;{ }^{13} \mathrm{C}$ NMR $\left(151 \mathrm{MHz}, \mathrm{CDCl}_{3}\right) \delta 202.60,165.10$, $164.80,134.32,134.11,132.37,128.86,128.79,114.16$, 108.01, 101.80, 69.34, 26.24; APCI-HRMS m/z: calcd for $\mathrm{C}_{15} \mathrm{H}_{14} \mathrm{ClO}_{3}\left(\mathrm{MH}^{+}\right), 277.0626$, found 277.0617.

\section{2-Acetyl-5-(3-iodobenzyloxy)phenol (2h)}

The title compound (beige crystals) was prepared in a yield of $58 \%$ : $\mathrm{mp} 143.7^{\circ} \mathrm{C}-144.6^{\circ} \mathrm{C}$ (ethanol). ${ }^{1} \mathrm{H} \mathrm{NMR}(600 \mathrm{MHz}$, $\left.\mathrm{CDCl}_{3}\right) \delta 12.72(\mathrm{~s}, 1 \mathrm{H}), 7.76(\mathrm{~s}, 1 \mathrm{H}), 7.64(\mathrm{dd}, J=16.8,8.5 \mathrm{~Hz}$, $2 \mathrm{H}), 7.35(\mathrm{~d}, J=8.2 \mathrm{~Hz}, 1 \mathrm{H}), 7.11(\mathrm{t}, J=7.8 \mathrm{~Hz}, 1 \mathrm{H})$, 6.51-6.43 (m, 2H) $5.00(\mathrm{~s}, 2 \mathrm{H}), 2.54(\mathrm{~s}, 3 \mathrm{H}) ;{ }^{13} \mathrm{C}$ NMR $\left(151 \mathrm{MHz}, \mathrm{CDCl}_{3}\right) \delta 202.62,165.10,164.73,138.13,137.30$, 136.24, 132.40, 130.35, 126.53, 114.21, 108.01, 101.80, 94.49, 69.06, 26.25; APCI-HRMS m/z: calcd for $\mathrm{C}_{15} \mathrm{H}_{14} \mathrm{IO}_{3}$ $\left(\mathrm{MH}^{+}\right), 368.9982$, found 368.9980 .

\section{2-Acetyl-5-(3-methylbenzyloxy)phenol (2i)}

The title compound (clear needles) was prepared in a yield of $53 \%$ : $\mathrm{mp} 98.6^{\circ} \mathrm{C}-100.8^{\circ} \mathrm{C}$ (ethanol). ${ }^{1} \mathrm{H}$ NMR $(600$ $\left.\mathrm{MHz}, \mathrm{CDCl}_{3}\right) \delta 12.73(\mathrm{~s}, 1 \mathrm{H}), 7.62(\mathrm{~d}, J=8.8 \mathrm{~Hz}, 1 \mathrm{H}), 7.27$ 
(t, $J=7.5 \mathrm{~Hz}, 1 \mathrm{H}), 7.23-7.17(\mathrm{~m}, 2 \mathrm{H}), 7.14$ (d, $J=7.5 \mathrm{~Hz}$, 1H), 6.53-6.47 (m, 2H), $5.03(\mathrm{~s}, 2 \mathrm{H}), 2.54(\mathrm{~s}, 3 \mathrm{H}), 2.36$ $(\mathrm{s}, 3 \mathrm{H}) ;{ }^{13} \mathrm{C}$ NMR $\left(151 \mathrm{MHz}, \mathrm{CDCl}_{3}\right) \delta 202.55,165.20$, $165.12,138.40,135.69,132.29,129.05,128.56,128.24$, $124.61,113.99,108.11,101.78,70.25,26.19,21.37$; APCIHRMS m/z: calcd for $\mathrm{C}_{16} \mathrm{H}_{17} \mathrm{O}_{3}\left(\mathrm{MH}^{+}\right)$, 257.1172, found 257.1157 .

\section{2-Acetyl-5-(4-methylbenzyloxy)phenol (2j)}

The title compound (beige crystals) was prepared in a yield of $48 \%$ : mp $98.0^{\circ} \mathrm{C}-99.5^{\circ} \mathrm{C}$ (ethanol). ${ }^{1} \mathrm{H}$ NMR $(600 \mathrm{MHz}$, $\left.\mathrm{CDCl}_{3}\right) \delta 12.72(\mathrm{~s}, 1 \mathrm{H}), 7.61(\mathrm{~d}, J=9.2 \mathrm{~Hz}, 1 \mathrm{H}), 7.29$ (d, $J=8.0 \mathrm{~Hz}, 2 \mathrm{H}), 7.19$ (d, $J=7.8 \mathrm{~Hz}, 2 \mathrm{H}), 6.51-6.45$ (m, $2 \mathrm{H}), 5.03(\mathrm{~s}, 2 \mathrm{H}), 2.53(\mathrm{~s}, 3 \mathrm{H}), 2.35(\mathrm{~s}, 3 \mathrm{H}) ;{ }^{13} \mathrm{C}$ NMR $\left(151 \mathrm{MHz}, \mathrm{CDCl}_{3}\right) \delta 202.54,165.23,165.13,138.16,132.76$, 132.28, 129.35, 127.67, 113.97, 108.15, 101.80, 70.15, 26.20, 21.19; APCI-HRMS m/z: calcd for $\mathrm{C}_{16} \mathrm{H}_{17} \mathrm{O}_{3}\left(\mathrm{MH}^{+}\right)$, 257.1172, found 257.1159.

\section{2-Acetyl-5-(3-cyanobenzyloxy)phenol (2k)}

The title compound (white powder) was prepared in a yield of $65 \%$ : $\mathrm{mp} 125.0^{\circ} \mathrm{C}-125.8^{\circ} \mathrm{C}$ (ethanol). ${ }^{1} \mathrm{H} \mathrm{NMR}(600 \mathrm{MHz}$, $\left.\mathrm{CDCl}_{3}\right) \delta 12.71(\mathrm{~s}, 1 \mathrm{H}), 7.71(\mathrm{~s}, 1 \mathrm{H}), 7.67-7.59(\mathrm{~m}, 3 \mathrm{H})$, 7.50 (t, $J=7.8 \mathrm{~Hz}, 1 \mathrm{H}), 6.50$ (dd, $J=8.9,2.5 \mathrm{~Hz}, 1 \mathrm{H}), 6.44$ (d, $J=2.4 \mathrm{~Hz}, 1 \mathrm{H}), 5.10(\mathrm{~s}, 2 \mathrm{H}), 2.55(\mathrm{~s}, 3 \mathrm{H}) ;{ }^{13} \mathrm{C} \mathrm{NMR}$ $\left(151 \mathrm{MHz}, \mathrm{CDCl}_{3}\right) \delta 202.67,165.09,164.35,137.51,132.50$, $131.83,131.43,130.65,129.50,118.44,114.39,112.89$, 107.91, 101.78, 68.70, 26.27; APCI-HRMS m/z: calcd for $\mathrm{C}_{16} \mathrm{H}_{14} \mathrm{NO}_{3}\left(\mathrm{MH}^{+}\right), 268.0968$, found 268.0971.

\section{2-Acetyl-5-(4-cyanobenzyloxy)phenol (2l)}

The title compound (white powder) was prepared in a yield of $73 \%$ : $\mathrm{mp} 145.9^{\circ} \mathrm{C}-147.6^{\circ} \mathrm{C}$ (ethanol), lit. $\mathrm{mp} 147^{\circ} \mathrm{C}-148$ ${ }^{\circ} \mathrm{C} .{ }^{4}{ }^{1} \mathrm{HNMR}\left(600 \mathrm{MHz}, \mathrm{CDCl}_{3}\right) \delta 12.70(\mathrm{~s}, 1 \mathrm{H}), 7.66(\mathrm{~d}, J=8.2$ $\mathrm{Hz}, 2 \mathrm{H}), 7.64$ (d, $J=8.9 \mathrm{~Hz}, 1 \mathrm{H}), 7.51$ (d, $J=8.2 \mathrm{~Hz}, 2 \mathrm{H}), 6.49$ (dd, $J=8.9,2.5 \mathrm{~Hz}, 1 \mathrm{H}), 6.43$ (d, $J=2.5 \mathrm{~Hz}, 1 \mathrm{H}), 5.13$ (s, 2H), 2.54 (s, $3 \mathrm{H}) ;{ }^{13} \mathrm{C}$ NMR $\left(151 \mathrm{MHz}, \mathrm{CDCl}_{3}\right) \delta 202.65,165.06$, 164.34, 141.23, 132.48, 132.45, 127.53, 118.48, 114.38, 112.01, 107.83, 101.85, 68.91, 26.25; APCI-HRMS m/z: calcd for $\mathrm{C}_{16} \mathrm{H}_{14} \mathrm{NO}_{3}\left(\mathrm{MH}^{+}\right), 268.0968$, found 268.0982.

\section{2-Acetyl-5-[4-(trifluoromethyl)benzyloxy] phenol $(2 \mathrm{~m})$}

The title compound (clear needles) was prepared in a yield of $39 \%$ : $\mathrm{mp} 85.6^{\circ} \mathrm{C}-87.0^{\circ} \mathrm{C}$ (ethanol). ${ }^{1} \mathrm{H}$ NMR $(600 \mathrm{MHz}$, $\left.\mathrm{CDCl}_{3}\right) \delta 12.70(\mathrm{~s}, 1 \mathrm{H}), 7.66(\mathrm{~d}, J=8.2 \mathrm{~Hz}, 2 \mathrm{H}), 7.64(\mathrm{~d}$, $J=8.9 \mathrm{~Hz}, 1 \mathrm{H}), 7.51(\mathrm{~d}, J=8.2 \mathrm{~Hz}, 2 \mathrm{H}), 6.49(\mathrm{dd}, J=8.9,2.5 \mathrm{~Hz}$, $1 \mathrm{H}), 6.43(\mathrm{~d}, J=2.5 \mathrm{~Hz}, 1 \mathrm{H}), 5.13(\mathrm{~s}, 2 \mathrm{H}), 2.54(\mathrm{~s}, 3 \mathrm{H}) ;{ }^{13} \mathrm{C}$
NMR (151 MHz, $\left.\mathrm{CDCl}_{3}\right) \delta 202.65,165.11,164.63,139.89$, 132.45, 127.39, 125.64 (q), 114.30, 107.94, 101.87, 69.19, 26.24; APCI-HRMS m/z: calcd for $\mathrm{C}_{16} \mathrm{H}_{14} \mathrm{~F}_{3} \mathrm{O}_{3}\left(\mathrm{MH}^{+}\right)$, 311.0890 , found 311.0866 .

\section{2-Acetyl-5-butoxyphenol (2n)}

The title compound (white powder) was prepared in a yield of $47 \%$ : $\mathrm{mp} 42.7^{\circ} \mathrm{C}-43.1^{\circ} \mathrm{C}$ (ethanol), lit. $\mathrm{mp} 38^{\circ} \mathrm{C}-40^{\circ} \mathrm{C} .^{5}$ ${ }^{1} \mathrm{H}$ NMR $\left(600 \mathrm{MHz}, \mathrm{CDCl}_{3}\right) \delta 12.72(\mathrm{~s}, 1 \mathrm{H}), 7.59$ (d, $J=8.9 \mathrm{~Hz}, 1 \mathrm{H}), 6.43-6.36(\mathrm{~m}, 2 \mathrm{H}), 3.97$ (t, $J=6.5 \mathrm{~Hz}$, 2H), $2.53(\mathrm{~s}, 3 \mathrm{H}), 1.79-1.72(\mathrm{~m}, 2 \mathrm{H}), 1.46(\mathrm{~m}, 2 \mathrm{H}), 0.95$ $(\mathrm{t}, J=7.4 \mathrm{~Hz}, 3 \mathrm{H}) ;{ }^{13} \mathrm{C}$ NMR $\left(151 \mathrm{MHz}, \mathrm{CDCl}_{3}\right) \delta 202.45$, 165.71, 165.21, 132.21, 113.68, 107.98, 101.22, 68.05, 30.94, 26.16, 19.12, 13.75; APCI-HRMS m/z: calcd for $\mathrm{C}_{12} \mathrm{H}_{17} \mathrm{O}_{3}$ $\left(\mathrm{MH}^{+}\right), 209.1172$, found 209.1152.

\section{2-Acetyl-5-heptyloxyphenol (2o)}

The title compound (white powder) was prepared in a yield of $65 \%$ : $\mathrm{mp} 32.8^{\circ} \mathrm{C}-33.8^{\circ} \mathrm{C}$ (ethanol), lit. mp oil. ${ }^{6}{ }^{1} \mathrm{H}$ NMR $\left(600 \mathrm{MHz}, \mathrm{CDCl}_{3}\right) \delta 12.73(\mathrm{~s}, 1 \mathrm{H}), 7.60(\mathrm{~d}, J=8.9 \mathrm{~Hz}$, 1H), 6.44-6.36 (m, 2H), 3.96 (t, $J=6.6 \mathrm{~Hz}, 2 \mathrm{H}), 2.53$ (s, $3 \mathrm{H}), 1.79-1.72(\mathrm{~m}, 2 \mathrm{H}), 1.42(\mathrm{p}, J=7.1 \mathrm{~Hz}, 2 \mathrm{H}), 1.35-1.26$ (m, 6H), $0.87(\mathrm{t}, J=6.9 \mathrm{~Hz}, 3 \mathrm{H}) ;{ }^{13} \mathrm{C} \mathrm{NMR}\left(151 \mathrm{MHz}, \mathrm{CDCl}_{3}\right)$ $\delta$ 202.47, 165.73, 165.23, 132.22, 113.70, 108.02, 101.24, 68.40, 31.73, 28.97, 28.94, 26.19, 25.88, 22.58, 14.07; APCI-HRMS m/z: calcd for $\mathrm{C}_{15} \mathrm{H}_{23} \mathrm{O}_{3}\left(\mathrm{MH}^{+}\right), 251.1642$, found 251.1659 .

\section{4'-Benzyloxyacetophenone (3a)}

The title compound (clear flakes) was prepared in a yield of 55\%: $\mathrm{mp} 93.2^{\circ} \mathrm{C}-94.5^{\circ} \mathrm{C}$ (ethanol), lit. mp $93^{\circ} \mathrm{C}-94^{\circ} \mathrm{C} .{ }^{7}{ }^{1} \mathrm{H}$ NMR $\left(600 \mathrm{MHz}, \mathrm{CDCl}_{3}\right) \delta 7.92(\mathrm{~d}, J=8.9 \mathrm{~Hz}, 2 \mathrm{H}), 7.44-7.36$ (m, 4H), 7.34 (d, $J=7.2 \mathrm{~Hz}, 1 \mathrm{H}), 6.99$ (d, $J=8.9 \mathrm{~Hz}, 2 \mathrm{H})$, $5.11(\mathrm{~s}, 2 \mathrm{H}), 2.54$ (s, 3H); ${ }^{13} \mathrm{C}$ NMR (151 MHz, $\left.\mathrm{CDCl}_{3}\right)$ $\delta$ 196.74, 162.57, 136.13, 130.57, 130.48, 128.67, 128.22, 127.44, 114.50, 70.10, 26.34; APCI-HRMS m/z: calcd for $\mathrm{C}_{15} \mathrm{H}_{15} \mathrm{O}_{2}\left(\mathrm{MH}^{+}\right), 227.1067$, found 227.1063.

\section{2-Propanoyl-5-benzyloxyphenol (3b)}

The title compound (clear needles) was prepared in a yield of $62 \%$ : $\mathrm{mp} 112.0^{\circ} \mathrm{C}-113.4^{\circ} \mathrm{C}$ (ethanol), lit. $\mathrm{mp} 113^{\circ} \mathrm{C}-114^{\circ} \mathrm{C} .^{8}$ ${ }^{1} \mathrm{HNMR}\left(600 \mathrm{MHz}, \mathrm{CDCl}_{3}\right) \delta 12.81(\mathrm{~s}, 1 \mathrm{H}), 7.65(\mathrm{~d}, J=9.6 \mathrm{~Hz}$, 1H), 7.42-7.31 (m, 5H), 6.50 (dd, $J=7.0,2.5 \mathrm{~Hz}, 2 \mathrm{H}), 5.07$ (s, 2H), $2.93(\mathrm{q}, J=7.3 \mathrm{~Hz}, 2 \mathrm{H}), 1.21(\mathrm{t}, J=7.3 \mathrm{~Hz}, 3 \mathrm{H}) ;{ }^{13} \mathrm{C}$ NMR $\left(151 \mathrm{MHz}, \mathrm{CDCl}_{3}\right) \delta 205.34,165.13,164.87,135.87$, 131.44, 128.67, 128.27, 127.50, 113.46, 108.01, 101.93, 70.15, 31.15, 8.48; APCI-HRMS m/z: calcd for $\mathrm{C}_{16} \mathrm{H}_{17} \mathrm{O}_{3}$ $\left(\mathrm{MH}^{+}\right), 257.1172$, found 257.1170. 


\section{References}

1. Yates MH, Koenig TM, Kallman NJ, Ley CP, Mitchell D. An efficient synthesis of a multipotent eicosanoid pathway modulator. Org Process Res Dev. 2009;13(2):268-275.

2. Buckle DR, Outred DJ, Ross JW, et al. Aryloxyalkyloxy- and aralkyloxy4-hydroxy-3-nitrocoumarins which inhibit histamine release in the rat and also antagonize the effects of a slow reacting substance of anaphylaxis. J Med Chem. 1979;22(2):158-168.

3. Pisani L, Catto M, Nicolotti O, et al. Fine molecular tuning at position 4 of $2 \mathrm{H}$-chromen-2-one derivatives in the search of potent and selective monoamine oxidase B inhibitors. Eur J Med Chem. 2013;70:723-739.

4. Ma YT, Fan HF, Gao YQ, Li H, Zhang AL, Gao JM. Natural products as sources of new fungicides (I): synthesis and antifungal activity of acetophenone derivatives against phytopathogenic fungi. Chem Biol Drug Des. 2013;81(4):545-552.

5. Arnoldi A, Merlini L, Quadri ML, Bonsignori A, Melloni P, Varasi M. Synthesis and anticonvulsant activity of some benzopyranone imino derivatives of GABA and related compounds. Farmaco. 1991;46(5): 629-638.
6. Tunoori AR, Dutta D, Georg GI. Polymer-bound triphenylphosphine as traceless reagent for mitsunobu reactions in combinatorial chemistry: Synthesis of aryl ethers from phenols and alcohols. Tetrahedron Lett. 1998;39(48):8751-8754.

7. Zeng J, Tan YJ, Ma J, Leow ML, Tirtorahardjo D, Liu XW. Facile access to cis-2,6-disubstituted tetrahydropyrans by palladium-catalyzed decarboxylative allylation: total syntheses of $( \pm)$-centrolobine and (+)-decytospolides A and B. Chemistry. 2014;20(2):405-409.

8. Bobik A, Holder GM, Ryan AJ. Inhibitors of hepatic mixed function oxidase. 3. Inhibition of hepatic microsomal aniline hydroxylase and aminopyrine demethylase by 2,6- and 2,4-dihydroxyphenyl alkyl ketones and related compounds. J Med Chem. 1977;20(9):1194-1199.

\section{Publish your work in this journal}

Drug Design, Development and Therapy is an international, peerreviewed open-access journal that spans the spectrum of drug design and development through to clinical applications. Clinical outcomes, patient safety, and programs for the development and effective, safe, and sustained use of medicines are a feature of the journal, which has also been accepted for indexing on PubMed Central. The manuscript management system is completely online and includes a very quick and fair peer-review system, which is all easy to use. Visit http://www.dovepress.com/testimonials.php to read real quotes from published authors.

Submit your manuscript here: http://www.dovepress.com/drug-design-development-and-therapy-journal 